\title{
On healing the epidemic of MAD
}

\author{
J. GORDON KingSLEY, PHD
}

Dr. J. Gordon Kingsley (Figure) is a quick-witted speaker who gets to the heart of the issues that we deal with regularly. He knows health care, serving as vice president of development for Health Midwest, a major hospital and health care organization in Kansas City, Missouri. He is an educator who loves teaching. He has served as professor, dean, and president of William Jewell College located outside of Kansas City. Dr. Kingsley holds many honors and serves on many community boards. He is timeless, beginning running marathons in his 50s and completing 13. A dynamic speaker, he has been called "an affirmative interpreter of fundamental values for our time." He exudes enthusiasm and demonstrates candor, realism, and meaningful humor in his presentations. Fifteen years ago he challenged me personally in a talk entitled, "God is in the Business of Creating Springtime in Our Lives." In the following talk, culminating our annual Baylor management retreat, he reminded us that it was the first day of our new organization and then assured us "we can do it!"

-FRED ROACH

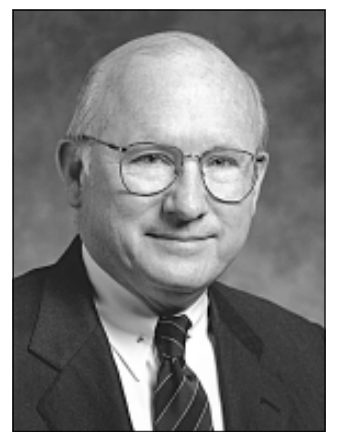

I still remember the day I first heard about seasonal affective disorder-SAD. Somebody told me about it, chortling; then I read about it, incredulously; then a mental health professional told me that it really, truly exists and is in DSM-IVthe official reference book on such things, meaning that it had achieved medical legitimacy; then I went to the Research Medical Center library to look it up in DSM-IV and sure enough found it as "a seasonal pattern specifier for mood disorder." Well, I tell PhD. Photo: copyright 199 Chuck Kneyse.

you, friends and neighbors, that I whacked the side of my head right then and there and said, "Glory be: this puppy has passed from folklore to medical science while we-uns was jist hangin' 'round hatin' winter." (That's the way we talk in the Ozarks.) And I remember whistling under my breath and murmuring to myself, paraphrasing Shakespeare's Robin Goodfellow, "Oh brave new world, that hath such ailments in it."

Prior to this discovery, you see, I thought you just felt bad in bleak midwinter, when days were short and nights cold and roads foul and noses raw and people bundled and cars skidding and skies gray and lowering and winds frigid and biting. After several days of that, you felt not only bad but rotten. And, after several more days of it, you felt not only rotten but also miserable. Then, if you but endured, the seasons would change, spring would come, all would be right in life again, and you would feel a darn site better.

I foolishly thought, in my medical naiveté, that this is all natural, normal, ordinary. The way things are. The order of nature and life.

You can imagine, then, what a blessed revelation it was to discover seasonal affective disorder officially written up in DSMIV. Now, I didn't just feel crappy; I had a medical problem. Or at least a psychological problem. And if I had a medical/psychological problem, then I should expect, and could expect, a medical/ psychological solution. I was, in fact, a victim. I don't know of whom or what I was a victim - whether it was God for sending winter, or my boss for making me work through winter, or my parents who seemed to be responsible for anything that is wrong with me, or whether I was a victim of simply-as my freshman students used to write- "this modern world of today in which we live now-currently—at this point in time." But, by declaring victimhood and expecting solutions from somebody else, somewhere, I could suddenly become an object of pity, at least self-pity. And I could expect, demand, that other people sympathize with me, empathize with me, care for me, listen to me, love me. After all, I was afflicted, with seasonal affective disorder. I was SAD.

(I have a friend, wife of a lawyer, who was diagnosed with seasonal affective disorder and sent off to a resort in Cozumel for the month of January. I rather like that prescription, which makes me rather like the diagnosis. Is it possible that I could go hang out on a beach through the winter and, instead of being a bum, I could be a patient, a recovering victim? And might I even get it paid for by some kind of health or disability insurance? The possibilities boggle the imagination.)

Well, friends and neighbors, having discovered seasonal affective disorder and finding it a noble problem, I come to you today as harbinger of a new ailment, one affecting many of us in this room, affecting our respective professions, and affecting the national body politic.

From Health Midwest, Kansas City, Missouri.

Presented at the Baylor management retreat at Barton Creek Resort, Austin, Texas, on November 2, 1999.

Corresponding author: J. Gordon Kingsley, PhD, Health Midwest, 2310 East Meyer Boulevard, Suite B-15, Kansas City, Missouri 64132 (kingsley@crn.org). 
My new ailment, discovered just in the last few days as I was writing this speech, is called not seasonal affective disorder, or $\mathrm{SAD}$, but rather medical affective disorder, or MAD. It is not yet in DSM-IV, but its appearance there is inevitable in that it is such a useful malady. I commend it to your thinking and to your care. Love this sickness. Embrace this disorder. Draw this ailment, this malady, to your breasts. Suck it in, inhale it, imbibe it. For, verily, it will do you great good. If you are very afflicted or very lucky, it might even yield you a January in Cozumel.

And what is medical affective disorder? It is, by definition (which I made up, of course), "the distress, anger, dis-ease, or dismay arising from the practice of, proximity to, or perpetration of medicine." In lay terms, it is the discovery that health care, which once looked so good as a profession or a community service, feels like it is now not only in the toilet but all the way to the outhouse. (That's the way we talk in the Ozarks.) It is feeling victimized, betrayed, impotent, frustrated in the face of what has happened or what we think has happened, in medicine during our short lifetime.

Like many medical/psychological maladies, it is subject to some ambiguity, and it may have different manifestations at different phases of our lives. For example, a young medical student may say, "I am just mad about medicine," suggesting enthusiasm and interest, if not enchantment, over a newly chosen profession. An older clinician, making his or her way through the managed care minefields, may say, "Practicing medicine today makes me mad," indicating anger, hostility, "I've had it." A hospital administrator may say, "This whole cost containment thing drives me mad," indicating incipient insanity-a characteristic of many hospital administrators, we would agree. The medical student is enthusiastic, the doc is angry, the administrator is out of his ever-lovin' mind frustrated. All are-or have-MAD. All are proper examples of medical affective disorder.

Nor is the disorder experienced just by those of us in this room. It has become a national malady of gargantuan proportions-a veritable epidemic of MAD has been let loose upon the world through the dramatic, traumatic evolution-shall we say revolution - in health care in our lifetime. Medical affective disorder is a severe anxiety reaction that afflicts the public at large as well as those of us who are, in greater or lesser degrees, "professionals" in health care, whether we be clinical practitioners or administrators or concerned and committed board members.

Causes of the disorder are not difficult to trace. For the public, they have to do with the sheer size of the health care apparatus, its consequent depersonalization, the rising dominance of technology in medicine, and the esoteric quality of medical language. I'm sure there are other elements contributing to the anxiety, which can be summarized in the word change-monumental change, rapid change, irreversible change, irrepressible change, change that has left us breathless, reeling, in its wake. Change always brings anxiety. How could there be anything but anxiety-medical affective disorder-for a public that has seen such gigantic and precipitous alterations in that sector of life that affects our most intimate selves-our bodies, our minds, life, death, sickness, health, the well-being of ourselves and those we most love-wives and husbands and children and parents and grandparents. The public is frightened. The public has MAD.
For professionals, the anxieties are similar, created by similar changes and affecting our livelihoods as well.

For example, you are a physician. Your training was long, arduous, expensive. In your internship and residency you served as brilliant, highly educated slave labor. Setting up your practice was incredibly costly, to say nothing of paying off your loans. You endured it all, year after year after year, because you could see great rewards "out there," a brightly glowing light at the end of a very long tunnel. You would get to practice medicine, using your talents and skills to their ultimate degree. You would do good for others; you would be a healer. You would have independence, being self-employed, calling the shots, controlling your schedules, being "free" in every sense of the word. You would be respected in the community. And you would make, not money, but MONEY: you would have a large-maybe a very large—income, with all the comfort and security and sense of well-being that entails.

You believed this because you saw it all happening with doctors you observed. You had reasoned, reasonable, legitimate expectations, based on direct observation. You expected a certain lifestyle, and-ah, here's the rub—so did your spouse. You anticipated, prepared, maybe even borrowed with a certain reality in mind.

And suddenly, with a rug-jerk, all changed, changed utterly. You are not independent, free in your practice, but are hedged in and dictated to and muscled over by all manners of payors, investigators, systems, insurers, agencies, bureaucracies. Your paperwork piles high, mountains of forms and reports and administrivia that hide the view if not the vision. Your income is good but nothing like you expected. You are respected in the community but also suspected as one of those rich doctors who are ripping us all off.

It is jarring. You anticipated one kind of life, professional and personal; you got another. Small wonder the Kansas City Star on April 27 reported on docs' unionizing - carrying union cards! Doctors! Small wonder doctors of my generation relish the prospect of retirement. As one physician friend told me, "While I could still practice medicine, I loved it; when I became an indentured servant to multiple bureaucracies at half the income, I quit."

Physicians are angry. Perhaps even you as a physician leader suffer from some degree of medical affective disorder: you are MAD.

The same goes for hospital administrators, who seek only to do good in the community, and also well - that is, to make a decent living for their families. Instead, they are hunted down, harassed by investigators, indicted, convicted. It pains us to see what happens to good people, especially when we know them and know that they are good people. Especially when we read that 4700 of America's 6000 hospitals are under investigation for fraud: 4700 of 6000 , leaving only 1300 of 6000 not under investigation. I submit to you that the hospital business simply does not draw that many crooks into its ranks- there are much easier ways to make money if one is intent on dishonesty.

It is therefore not surprising if you as an executive should hunker down, should manage defensively, should cover your personal and institutional backsides, should write nothing, say nothing, do nothing, think nothing, lest you be vulnerable. Bold actions yield to fearful finger drumming atop polished desks. Bold 
ideas yield to tired clichés. Bold visions yield to safe, pitiful little thoughtlets, stripped down and neutered by prudent legal advisers, turned into glossy pabulum by hopeful PR hacks. Innovation is replaced by thick policy manuals. Dreams are replaced by fears. It is once again the classic case of the bland leading the bland. And good people who came into hospital administration to do good work are frustrated to the core of their being. Now you as administrators are victims of medical affective disorder. You are MAD.

It is the nature of things in the hospital world of today in which we live now, currently.

Not to be tedious, but let me embroider this theme just a little bit further to make the point.

Consider the public, what we used to call the common man, when he, or she, comes up against the sheer size and complexity and (to him) the confusion of our modern health care system. Picture in your mind a good ole boy from my old hometown of Hardin, Missouri, down in the river bottoms (Hardin is a suburb of Henrietta, out from Norborne, down the road from Carrollton, across the river from Lexington, one wagon greasing from Richmond-you get the picture). A health problem rears its fearful head in ole Bill's family—say his wife needs some kind of surgical procedure, except to him it ain't no surgical procedure, it's "a operation." And it is scary. Because "the wife," as he calls her, is feeling "poorly," as he says, he loads her up in the pickup and hauls her to their family doc to see what they should do. "Go to a specialist in Kansas City," the family doc says, which adds to their fears. If you're from Hardin, you see specialists—or go to Kansas City — only when you're about to die, and maybe not then. The doctor sends ole Bill and the missus to a surgicenter, I think he called it. What in damnation is that? Or to a tertiary care facility. "It's not my tertiary that needs care, it's my wife!" Then there is insurance to think about-God, is there insurance to think about. How are we gonna pay for this, when a hospital room costs a lot more than a room in a mo-tel?

Bill's pickup truck wheels into the parking lot of Research Medical Center, say, and the first thing he finds is there's no place to park. So he walks the wife a quarter of a mile or so across the blacktop, comes into the front door of the hospital, and from that point on he doesn't have a clue. He stands for 30 minutes or so looking at the donor wall, hoping it is a directory leading him to his doctor or to some place where he can get help. He looks round about himself, trying to appear cool, the way we looked down in Hardin when we gathered in front of Dan Myer's grocery store, kind of squatting on our heels, to chew, or spit, or whittle, or cuss a little bit, or tell a yarn, or if we were really talented to chew and spit and whittle and cuss and tell a yarn all at the same time. But it's hard to look cool when you don't know where you're at and you need to find the specialist-doctor, but all you can see around you is a gift shop, a chapel, a café, an elevator, some restrooms, and a place to pay - to pay for something you ain't even had yet. I'm just trying to say that it is scary, because it is so big, because it is so complicated, because nothing looks right or sounds right or is easy.

And you don't have to be good ole Bill from Hardin. You can be, like my own family, Bob and Betty from suburban Blue Springs, tooling in in your Jeep Cherokee, classy people who, when we're planning a big night out for dinner, decide whether it's going to be a place with a real waitress—-that is, Perkins-or a place with a microphone-that is, Sonic. The health care system is equally confusing, because of its hugeness and its complexity. Or let's say you are Latasha, an African American mother who lives 6 blocks from your hospital. Or J. Savvy Make-a-deal from the high-rent suburbs, a corporate dasher, if not Dancer or Prancer or Donner or Blitzen, who has never been sick a day in his life and suddenly has chest pains and drives himself or calls the wife off the golf links on his cell phone, trying to get to your city's most fashionable hospital: even if you are savvy and sophisticated, it is hard to know what to do when suddenly your body stops working right.

A large hospital is a symbol of the whole health care system in that it is a labyrinth, a maze, a place where you can't get lost because you never were found in the first place. A doctor is not a doctor anymore to the patient-what an apt word, patient—but is instead a specialist, or a subspecialist, or a sub-subspecialistnot a real doctor at all, but a bone pinner or eyeball plucker.

And while the patient is hurting, and confused, and frightened, and wondering where to go and what to do, he believes in his heart of hearts that these hospitals and doctors are getting rich as skunks. So now the patient is not only scared, he is disaffected. He has MAD with a vengeance.

Size is not the primary villain. Worse is the inevitable depersonalization that comes with size, a source of enormous MAD when patients, clients, persons, are reduced to being "cases," numbers, capitated heads. When we, usually unwittingly and unintentionally, gravitate toward treating diseases instead of people; when patients, clients, persons, are reduced to feeling like slabs of meat on an examination table; when people become merely payors, or feel that they are, then medical affective disorder becomes an epidemic.

Each of us has his stories of depersonalization, as patient or as professional. Wife Suzanne, in one of the hospitals I serve in our Health Midwest system, first being quaintly puzzled as an admitting clerk argued with her about what her own - that is Suzanne's-name is, then lying in pain after gallbladder surgery went bad, was told by a well-meaning but insensitive technician who came to draw blood, "You're my last stick of today." There is more than a hint of depersonalization in being anyone's "last stick of today," particularly after having been assured that you don't even know your own name. And Suzanne was, is, a young and healthy woman. It gets much worse if you are an old guy like me.

Two summers ago, for example, I-your obedient, humble servant-became a patient in our system, a system I admire and promote and serve and, on some days, love. It was a simple enough thing, and it happens to many-I had helped a guy haul his heavy fishing boat up onto the shore on the little lake where we live and had felt a little twinge of strain in my back. Well, you medical people know the story, and a bunch of others in this crowd know it too. A couple of days later I was in my office, leaned over to pick up a single letter from the credenza, and lo, the death angel struck. There was a pain in my left calf more excruciating than anything I had ever felt in the history of the world. My office is about 50 yards from Research Hospital, and I was mentally calculating how I could call the Research Eagle helicopter to airlift me across that glacial space to the emergency room. 
Now, old fart Gordon, you have become a "case," a consumer, even ultimately a payor, in the health care system. And what a revelation it is!

With some very notable exceptions from some very notable individuals - precious to me in my mind and my memory are those folks-I now became depersonalized, an object on a conveyor belt that made its way through various doctors' offices, various wings of a hospital, various facilities in the corridors of those wings, all these offices and clinics and facilities and labs having great difficulty in communicating, though all were within easy walking distance and certainly easy telephone or fax or Cerner computer network distance of one another.

As an object on that conveyor belt, a case, I observed a bewildering thing. From the get go, I was denuded of any respect normally accorded to representatives of God's highest creation, us "humans merely being" as the poet e e cummings calls us. Admitting clerks were the worst in my brief experience (and I am sorry to say it in that they are the first folks we meet in a hospital, forming our first impressions). They were followed hard after by assorted cheery-voiced women bobbing in and out of examining rooms dressed in official hospital costumes babbling baby talk at me.

I was treated as if I were weak-which, of course, I was, being in terrible pain. I was treated as consummately ignorant, which I was, given the unfamiliar setting and the unfamiliar language I was hearing. Medical language, so necessary for scientific accuracy, also contributes to a serious depersonalization when it is not explained. So, for example, I was glibly told that I was to report to the Pain Institute on the third floor of Research Medical Center for an epidural. "What is an epidural?" I blandly asked. "It is something we do for your pain," came the clipped and somewhat annoyed response. I wanted to know a wee bit more than that, especially since I had sort of obliquely grasped the possibility that someone might be playing a dart game on my spine, so I look up the word epidural on a CD-ROM in my little laptop, a disk that contains a dictionary and an encyclopedia and God knows what other lore. I waited expectantly-note that, expectantly—as the disk whirred and the computer clicked and the answer came up on the screen - a whole section of information on childbirth. "Oh my God," said I. "I am worse off than I thought. I am about to have a baby." I was treated as ignorant, which I was. But I was also treated as stupid, which I was not.

And, I was treated as dependent. I think that is the rationale for the aforementioned baby talk. I was weak, I was hobbling, I was hurting, I was old, and therefore I presumably could not understand any words unless they were in one syllable and pronounced with a happy singsong nursery rhyme sort of voice, usually chanted at me with the pronoun "we": "How are we feeling today?" "Now shall we get up on the examining table and drop our drawers?" I finally told one cheery soul that the only persons entitled to call themselves we are God, a king, a Siamese twin, or a man with a tapeworm.

I found myself resorting to various mechanisms to try to offset the depersonalization. I kept hearing the words of the poet William Butler Yeats ringing in my head: "An aged man is but a paltry thing ... unless / Soul clap its hands and sing. ..." And so, quite deliberately, I began to try to make my soul clap its hands and sing as I went into examining room after $\mathrm{x}$-ray room; after the MRI lab; after the area labeled "Neurophysiology Lab: EEG, EMG, Evoked Potential"; after the Pain Institute; after the physical therapy room; after the eternal, everlasting, infernal, ubiquitous admitting room, and dressing rooms, and examining rooms. I found myself "dressing up" to go to the doctor, on the theory that if I were wearing a tie and a reasonably well-tailored suit I might earn treatment as a more mature and responsible person - not from the docs, let me say again, who almost uniformly were good in their handling of this patient-but from the harried, hurrying, file-toting, spear carriers of the various hospital and medical offices. I found myself trying to walk tall, pulling myself up to my full glorious height, which is less than impressive when you are 5'7", bald, and hobbling. I found myself wishing for a full head of shaggy hair, another half foot in height, a muscular build, maybe the shedding of 30 years. It was not a precious pride at work, at all; it was just wanting to be a person, a human being, instead of a defective leg of pig. I found myself calling out all the resources I could muster in order to earn, even to demand, a modicum of respect. I began name dropping, shamelessly, though I agree with my friend Sir David G. T. Williams, former vice chancellor of Cambridge University, who is fond of saying, "I hate name droppers. As I was telling the queen last week, it is terribly off-putting." I would therefore let it be known that I knew, personally, the big boss of our system. I knew the chairman of the board. I knew the hospital administrator. I knew the chaplain (that one didn't help). Ah-this one worked-I knew the chief financial officer. I took to wearing my badge as a Health Midwest vice president-we never wear our badges, but I did when going to a hospital in quest of further indignities. I made references to esteemed physicians. I joked with those intent on perpetrating atrocities upon my body. When confronted with the baby talk, I used big words-and I know a lot of big words, some of them all the way up to 3 syllables. I asked questions about treatments. I made notes. I postured being nonintimidated. And, the most effective tactic of all-I treated my tormentors as persons, asking about their training, asking about pictures on the credenza behind the desk, asking about family members, letting the costumed perps know I considered them real people and silently, by implication, expected the same from them.

Some of the tactics worked, except when I was committing the unnatural perversion of lying near-naked on a moving slab inside an MRI machine, impersonating toothpaste in a tube with all sorts of clanking going on as your obedient, humble servant was being squished. It was as weird as the day an ophthalmologist - not one of ours — was humming "Send in the Clowns" as he bent over me to remove a cataract, with my plaintive whine, "Don't forget me. I'm the clown who's down here on the table" as his background music. I quite simply felt no longer present and part of the proceedings, yet I had the most to gain or lose from the whole operation.

Now factor in the cost from my season as a patient in our system. The bills began coming in, some of them seeming quite reasonable for the skilled services that were provided. Others seemed less than reasonable, as for example the 70-something dollars charged when a physical therapist - a fine and helpful young woman-told me she didn't have any instructions from the physician and she therefore could not recommend any exercises or therapies, but I might consider propping my leg up when 
I was sitting around watching TV (the possibility of my going to work or living some kind of reasonably active life that did not include watching TV being apparently beyond her realm of imagining). Seventy bucks to tell me she didn't have anything to tell me but I might want to prop my leg up! Hey, I could have figured that one out for zero bucks! Total bills for this episode finally amounted to several thousand dollars, almost all of which were paid by the 2 insurance programs that we carried. Though, as any hospital or physicians involved would tell you, the payments came very slowly. And several of those payments came only when I-who have made a life commitment to the cause of keeping insurance companies relatively honest in my personal dealings with them — called, and called again, and called again, and called again, following up on the bills and the disposition of the bills by the insurer.

By the time one has been in terrible pain, has bounced around from office to office and clinic to clinic and lab to lab and corridor to corridor and maze to maze and labyrinth to labyrinth and baby-talking wench to baby-talking wench, all the while being treated as a borderline imbecile; and by the time one has been billed for this privilege at least one-half the cost of a new Volkswagen Beetle; and by the time one has dealt with the insurance company so blankety-blank many times that me and that nice girl assigned to my account are close friends and my wife and her husband are both suspecting that we are more than friends, so frequently am I calling her-by that time, I tell you, you have an advanced case of medical affective disorder. If you are not MAD, you ought to be.

And, I should probably observe that I am scarcely a typical patient. I work in a hospital system. I like these people and these places. I admire what is done there and sell it to the large philanthropic community with considerable zest and joy in the work. I am reasonably literate and more than reasonably educated. I am resilient, have some sense of humor, and have a high tolerance for ambiguity. Take away any of those qualities-the dayto-day contact with health care, the education, the experience of life; replace a sense of humor with fear, replace flexibility with a black-and-white view of life, replace a kind of graceful acceptance of what comes with a sense that I am a victim of forces larger than me-and you have a truly advanced case of MAD, with fury and anger running rampant through our little universe.

Now-and I am, mercifully, much closer to being finished than you dream-I must observe once again that the same medical affective disorder striking patients through the size and complexity and depersonalization of health care in this modern world of today in which we live now also affects physicians, hospital administrators, board members, medical care providers at every level, through the same villainous qualities.

Doctors themselves are subject to depersonalization nowadays, as much so as the patients they serve. Once upon a time, a boy or girl growing up and wanting to be a doctor thought in human terms. You would some day set up an office, get to know your patients and their families, look after them, make things better for them. As a child you had vague notions of specialties and knew that they were good things, but your images were mainly those of the village doctor. I remember a series of Peanuts cartoons in which Charlie Brown decided he wanted to grow up and become a doctor. But, he worried through one whole panel, he did not want to be one of these specialist city doctors but instead "a plain, humble country doctor," who could be with the people and know them and care for them. But, he fretted in the next day's strip, he did not want to live in the country while he was being a country doctor, and so he resolved that dilemma by deciding, "I will live in the city in a fine house. And then every morning I will get in my sports car and drive out in the country and be a plain, humble country doctor." But he fretted through the next day's panel about the anonymity of a country doctor, deciding that he would rather be famous than unknown. And he concluded the series by saying, "I know what I'll do. I will discover a cure for the common cold and become a plain, humble, world-famous country doctor." And, Charlie Brown concluded smilingly, "I'll be a regular M. Deity."

In that simple youth when many of us considered becoming doctors, managed care had not been invented, or if it had it was limited to some Kaiser industrial plant in some far-off foreign land like California. Medicare and Medicaid did not exist. In fact, the entire health insurance industry had scarcely been devised. These factors, plus the better science now done in medicine, plus the growth of the population, plus daily advances in technology, plus rising expectations of "consumers," have changed everything. Now it is very difficult to be an M. Diety, when the best one can hope for is to be one of the archangels in a large group practice attached to a large metropolitan hospital, being reimbursed at a fraction of one's billings by a government agency or an insurance company that is setting your rates. Maybe we had a period of greed that led to these changes-probably we did. Greed is one fairly predictable quality in the human equation, as we all know. But can anyone doubt that the tail is now wagging the dog when insurers pass the risk off to coalitions of physicians, who did not train to be insurance companies, who are not organized to be insurance companies, and who should not be spending their time becoming insurance companies. I want my doctor taking care of my medical needs, not calculating the actuarial probabilities or profit in this or that capitated setting.

In some instances, insurance companies have ceased to be insurance companies and instead are trying to be money collectors and distributors who pass the risk off onto aggregated physicians' practices. They collect the money while doctors and hospitals take the risk and do the work. The word facilitator comes to mind, but only in polite company. In other company, the word is pimp.

I do not mean to be unduly harsh. Insurers have their own pressures in this modern world of today. But certainly doctors are squeezed as much as many, more than most.

So, doctors become afflicted with, infected with, medical affective disorder. Everywhere I go these days, doctors not only have MAD, they are MAD. And that is a darn shame.

If all of us - as doctors, patients, executives, board membersall of us-suffer from MAD in greater or lesser degrees, if dashed hopes and thwarted expectations yield MAD, if legal pressures and bureaucratic demands yield MAD, if depersonalization and loss of independence yield MAD, if bigness of the health care system makes us feel smaller and therefore yields MAD, if lessened income yields MAD, if restrictions on how we can treat patients or operate hospitals yield MAD, then the question of treatment becomes paramount. The diagnosis is medical affec- 
tive disorder, MAD. What is the therapy, the cure? How do we get hold of something that is an epidemic in our society, first to contain it, then to heal it?

Let us first, following good scientific practice, dismiss those things that won't work.

Nostalgia is one of those things. Many of us, perhaps all of us, remember when things were different, and simpler, and more human, and more humane, when doctors worked on a fee-forservice basis and were widely respected patriarchs of the community, when hospitals did not advertise but just sat there being hospitals, and that was enough, because when people needed this place of refuge and sanctuary and hope they came on their own or with the help of their doctor, with no billboard or television ad or radio spot or sponsorship persuading them to do so; when "running a hospital" was a good job, a relatively straightforward job, that qualified you as a bona fide "pillar of the community" but did not tax your nights or weekends as well as your days and did not rub your nerve ends raw and did not jangle so hard against the secret places of your soul that you began to find yourself waking up in the dark of night asking, "Where did I put myself?" "Where did I lose myself?"

Many of us, maybe all of us, remember the simpler times, but the fact is they will not come back again. You cannot stuff the genie back into the bottle. You cannot shrink the elephant. Where does an 800 -pound gorilla sit? Where he wants to sit. And the health care system is in fact an 800-pound gorilla that is going to keep sitting on our heads if it wishes to do so, as it indeed does. "I like it right here just fine," says he, picking his simian teeth in our faces.

The simpler times will never return. Nostalgia feels good, but it is a false feeling good, a dream of what never was and will never be. Nostalgia won't cure MAD.

Nor will wishing cure medical affective disorder. We can wish the health care system to be smaller, more personal, more humane, more rational, more rewarding, more tractable, more happy. But wishing doesn't make it so. It doesn't cure MAD.

Even more important, and more to the point, blame doesn't cure MAD. In fact, it makes it worse. We have all seen this phenomenon: stress strikes, which it seems to do every day, and doctors blame hospital administrators. Patients blame doctors. Board members get kind of starchy with the executives who, after all, serve "at the pleasure of the board," and the board is not feeling much pleasure right now. Everybody blames the government or the insurance companies. And if we can't find anyone else to blame, we blame Bill Clinton or the lack of profit sharing in major league baseball or, if you live in Kansas City, Elvis Grbac.

There is a short-term shot of adrenaline or something hot inside ourselves when we blame others, and we somehow, by blaming, can let ourselves escape responsibility, step out of the center of the problem. But as my dear mother used to say, "Whenever you are pointing one finger at someone else, you are pointing three fingers back at your own self." Blame doesn't work.

And despair doesn't work. Shakespeare's Richard II says, as his kingdom and life and hopes are crashing around him, "Let us sit upon the ground and tell sad stories of the deaths of kings." Such despair creates nothing, builds nothing, helps nothing, resolves nothing. It is more a symptom than a solution of medical affective disorder. Though I have known several physicians of roughly my age who are looking toward retirement with some pleasure and satisfaction in that they can see a date when they are "out of this mess," believing so helps only that individual and not those who are left in the system as it is.

Instead of nostalgia, or wishing, or blame, or despair, the treatment I would propose is radical — that is, "from the roots"and has less to do with changing the system than it does with changing ourselves, our attitudes, and consequently changing the things we look at as crucial while we work within the system.

That is not to say the system should not be changed: it should, and that in substantial ways, and that every day. Our best minds should be always at work correcting, improving, adjusting, making better. It is like fixing our house so it becomes a better house, a happier, more livable place, more efficient, more usable, more beautiful. If we're going to occupy it, let's make it the best it can possibly be, even though it is consummately difficult to build the house while living in it.

But, at the end of the day, it is ourselves who are living in it, and who we are matters more than what it is. Any effective treatments for medical affective disorder take us back to the roots of why we came into medicine or health care in the first place.

Again, I refer to our childhood and youth, our early and idealistic professional years, when we came into health care with a motive to serve, to help sick people get well, to help healthy people stay healthy, to help individuals and families, to help communities be better. We felt we could make a living as doctors or administrators and of course wanted to- the more the better-but the main motive for many of us was to serve.

In that sense, we were thinking toward a profession-not just a job, not just a business, not just a role in society, but a profession-where we have something to profess, something to offer, something to advance, something to ameliorate, something to improve. It was not just a job, but a commitment-ourselves committed toward a worthy calling, a calling out of ourselves and out of our selfishness and out of our self-centeredness to do the good for other human beings in a world marked by many kinds of illnesses, individual and communal.

It is true of physicians, who by definition and oath are called out of themselves to heal others. It is true of hospital administrators: the root idea of administration, in fact, is to minister. The root meaning of executive is to act, to execute, to do what is good for persons and people and community. And it is true of board members, who fill these roles not for personal aggrandizement or personal gain but to serve, to do the good.

Would you agree to that? That our chief goals in health care are health and care? It is so radically, stunningly simple: "health care" consists of health and care. But then most great truths are stunningly simple.

The fact of the matter is, the bottom line is not the bottom line. The financial bottom line is critical, to be sure. Without positive results here, our work ceases to be. We close the doors, turn out the lights, lock up the shop, put a for sale sign in front of the property. We are done, finished, gone, caput, history, toast. And as Big Daddy says in Tennessee Williams' play Cat on a Hot Tin Roof, "When you're gone from here, boy, you're long gone and nowhere." Successful financial performance is critical. But it is not fundamental. I repeat it as if it were an incantation, a chant, a charm: the true bottom line in health care is health, and 
it is care. This is the bedrock, radical, from the roots, basic, fundamental bottom line. Sick people get well. Men and women die in comfort and dignity. Health is sustained. Care is tendered. Communities are made better. Families are comforted. Children are loved. I know this is "soft" and easily sneered at in the hardheaded "business world" of health care, the hard-eyed science of medicine. Because it is soft talk you can readily dismiss it as syrupy, mushy, irrelevant. But soft is not always bad. The heart is soft, but it pumps life. The brain is soft but is a seat of knowledge and wisdom. It is okay to care for people, even in a health care system.

The cure for medical affective disorder, then-the solution for MAD — is that we return to our first love, our first principles, the things that first turned us into doctors or called us to lead hospitals or lured us to hospital boards. We return to our care for humanity, to those high and noble motives that beckon us to live lives of greater purpose.

Incidentally, of course, this is great marketing. Watch patient satisfaction ratings zoom up when somebody really cares and lets a patient know that he or she cares. Watch census go up when the word gets out that our hospitals are caring places to be, existing for the well-being of the patient and not the convenience of the staff. Let the word get out that our boards and administrators really care about people, are more interested in health than in profits, and people will be beating down our doors. It is great marketing. But that is incidental to doing right, and being right, and living right, and creating the kind of great institutions that serve society well because they serve society nobly. This kind of worthy, selfless focus bit by bit becomes the medicine for MAD in ourselves and then, slowly, in the minds and loyalties of those we seek to serve.

It works something like this. When I was president of William Jewell College, maybe 5 years or so into that work, I was sure that we had painstakingly put the pieces of a great college together-person by person, program by program, plan by planand were now ready to take off. As a college, we would soar, swoop, sail, mount up with wings as eagles. We would become not just the best college in Missouri and not just the best college in the Midwest and not just the best college in America, but maybe the best college in the whole wide world. We were ready! I was ready!

Then, totally unexpectedly and without any warning, the dream unraveled. It happened the way it always happens: either we don't step up to the challenge before us or someone we are counting on very much does not deliver. And, suddenly, we were not about to soar and swoop and sail, but instead we were looking up to see bottom. It was a terrible reversal of hopes and dreams and expectations. I was angry, disappointed, frustrated. I had contracted the collegiate equivalent of MAD.

Now what do you do in a situation like that?

I had lots of advice-Job never lacks for his comforters. Some said, sympathetically, "Go talk to someone who would understand." But that would be someone like Father Weiss, president at Kansas City's Jesuit college, called Rockhurst-I wasn't about to go tell the competition how we had screwed up at William Jewell. Or they say, if you are a religious person as I am, "Talk to God about it." I thought about that, but I figured God had never been a college president, and if he were he would have fixed it by going "ZAP!" and I couldn't do that. Or they say, "Go deep within yourself to your own inner resources." I tried that, and it was just one depressed person talking to another depressed person.

So, I did what you are not supposed to do. I ran. I think psychologists call it "flight." I boarded a plane for the west of Ireland, where I love to go. I spent a time walking the rugged, beautiful coasts, listening to the Atlantic crash against the rocks, reading some great stuff, playing badly on an Irish tin whistle, and trying to figure out what to do.

One evening I was in Gus O'Connell's Pub in the town of Doolin in County Clare, where they say, "America is the next parish west," listening to 3 young Irishmen play and sing their music. I probably should not have been in a pub, for I was president of a Baptist college and Baptists have a very strict rule on drinking: They don't do it in front of each other. In fact, when I got back to campus and talked about the experience, I did not call it a pub at all but rather used the Irish word shebeen, whereupon a lovely southern lady, a member of the board of trustees, asked me, "What is a shebeen, Dr. Kingsley? Is that a beautiful Irish valley?" "Yes, ma'am," said I, "a shebeen is a beautiful Irish valley!"

I listened to the 3 young men in Gus O'Connell's Pub, and in the course of the evening, they sang an American folk song that you may know:

Inch by inch and row by row,

We're gonna make this garden grow.

All it takes is a rake and hoe,

And a piece of fertile ground.

Inch by inch and row by row,

Someone bless these seeds I sow.

Someone warm them from below,

'Til the rains come tumbling down.

There it was, and like a whack on the side of the head, I understood all. I knew exactly how it worked, and I knew exactly what I needed to do when I got back to the college and the work there.

Look what the song is saying. It says that never shall we, in a great work, soar and swoop and sail, take off into the sky for an easy victory. Always it will be hard work, darn hard work and lots of it, to make progress a little bit at a time- "Inch by inch and row by row." It is our work- "We're gonna make this garden grow. / All it takes is a rake and hoe"—our work that gets the job done.

But not just our work. There is also "a piece of fertile ground"- - that is, the gifts we have been given to use in achieving our successes. They are our talents, our education, our opportunities, our country, our families, our hospitals, our system, our colleagues. We work hard, but we do not work alone-the gifts of God are everywhere.

And, further, "Inch by inch and row by row / Someone bless these seeds I sow. / Someone warm them from below / 'Til the rains come tumbling down." This speaks of powers larger than we are, beyond us, that help us in any noble and good work. We cannot bless the seeds, but someone does. We cannot warm them 
from below, but some powers, forces, elements do. We cannot send the rain, but it comes, through no act of our own.

We work hard. We use the gifts that have been given us. And we accept the help of the powers larger than all of us-our shared efforts, our common vision, our mutual strengths, perhaps God himself.

We don't need to whine or whimper. We don't need to feel ripped off. We don't need to feel as if we are victims. We can banish medical affective disorder and all our anxiety and frus- tration by placing our hand to the work, feeling the gratitude for the gifts already given us, and being available to the powerful good forces that can flow through us for the good and health and healing of others.

We can do it. The great philosopher Vince Lombardi said it best: "We never lose! Sometimes the clock runs out on us, but we ... never ... lose."

Thank you very much. 